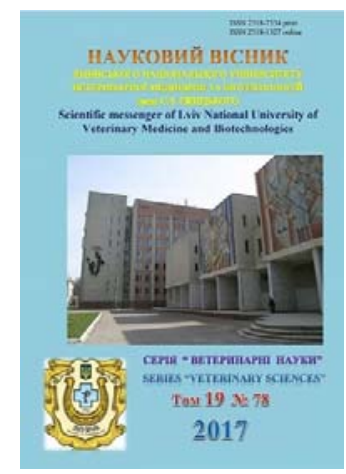

Науковий вісник Львівського національного університету ветеринарної медицини та біотехнологій імені С.З. Гжицького

Scientific Messenger of Lviv National University of Veterinary Medicine and Biotechnologies

doi:10.15421/nvlvet7807

ISSN 2518-7554 print

ISSN 2518-1327 online

$\underline{\text { http://nvlvet.com.ua/ }}$

УДК 619:083.72:576.8.094.29

\title{
Таксономічна характеристика РНК-геномних вірусів хребетних тварин і людини
}

\author{
О.С. Калініна \\ kalininaos@ukr.net \\ Львівський національний університет ветеринарної медицини та біотехнологій імені С.3. Гжицького, \\ вул. Пекарська, 50, Львів, 79010, Україна
}

Подано сучасну таксономію та номенклатуру РНК-геномних вірусів хребетних тварин і людини згідно з інформацією МКТВ випуску 2016 р. (ратифікація 2017 р.). Віруси хребетних (1269 видів) входять у 5 порядків, 38 родин, з яких 12 - ДНКгеномні та 26 - РНК-геномні, 12 підродин і 233 роди. РНК-геномні віруси хребетних (679 видів) класифіковано в 4 порядки, 26 родин, 6 підродин і 119 родів. Порядок Мопопеgavirales об'єднує родини Paramyхоviridae, Pneumoviridae, Rhabdoviridae, Filoviridae, Bornaviridae, Nyamiviridae i Sunviridae, порядок Nidovirales - родини Coronaviridae та Arteriviridae, порядок Bunyavirales - родини Hantaviridae, Nairoviridae, Peribunyaviridae i Phenuiviridae, порядок Picornavirales - pодину Picornaviridae. Родини Rhabdoviridae, Peribunyaviridae, Phenuiviridae, Nodaviridae, Reoviridae i Birnaviridae, крiм вipycis хребетних, містять віруси комах, а родини Rhabdoviridae, Phenuiviridae i Reoviridae - віруси рослин. $\epsilon$ один «плавучий» рід Deltavirus, який не входить до родин. Описано таксони вірусів: родини, підродини, роди, види. Названо типові види родів вірусів. Охарактеризовано основні таксономічні ознаки РНК-геномних вірусів хребетних: форма, розміри і структура віріонів - наявність зовнішньої ліпопротеїнової оболонки, тип симетрії капсиду (спіральний, ікосаедральний), структура вірусної РНК (кількість ниток, конформація, фрагментованість, полярність). Акцентовано увагу на особливостях репродукиї вірусів.

Ключові слова: віруси, РНК-геномні, порядки, родини, підродини, роди, види, типові, таксономічні ознаки.

\section{Таксономическая характеристика РНК-геномных вирусов позвоночных животных и человека}

\author{
О.С. Калинина
}

kalininaos@ukr.net

Львовский национальный университет ветеринарной медицины и биотехнологий имени С.3. Гәицкого, ул. Пекарская, 50, г. Львов, 79010, Украина

\begin{abstract}
Представлена современная таксономия и номенклатура РНК-геномных вирусов позвоночных животных и человека согласно с информачией МКТВ выпуска 2016 г. (ратификачия 2017 г.). Вирусы позвоночных (1269 видов) входят в 5 порядков, 38 семейств, из которых 12 - ДНК-геномные и 26-РНК-геномные, 12 подсемейств и 233 рода. РНК-геномные вирусы позвоночных (679 видов) классифииированы в 4 порядка, 26 семейств, 6 подсемейств и 119 родов. Порядок Mопопеgаvirales объединяет семейства Paramyxoviridae, Pneumoviridae, Rhabdoviridae, Filoviridae, Bornaviridae, Nyamiviridae u Sunviridae, порядок Nidovirales - семейства Coronaviridae и Arteriviridae, порядок Bunyavirales - семейства Hantaviridae, Nairoviridae, Peribunyaviridae и Phenuiviridae, порядок Picornavirales - семейство Picornaviridae. Cемейства Rhabdoviridae, Nodaviridae, Peribunyaviridae, Phenuiviridae, Reoviridae и Birnaviridae, кроме вирусов позвоночных, содержат вирусы насекомых, а семейства Rhabdoviridae, Phenuiviridae и Reoviridae - вирусы растений. Есть один «плавающий» род Deltavirus, который не входит в семейства. Описаны таксоны вирусов: семейства, подсемейства, роды, виды. Названы типовые виды родов вирусов. Охарактеризованы основные таксономические признаки РНК-геномных вирусов позвоночных: форма, размеры $и$
\end{abstract}

\section{Citation:}

Kalinina, O.S. (2017). Taxonomic characteristics of RNA-genomic viruses in vertebrates animals and human. Scientific Messenger LNUVMB, 19(78), $30-35$. 
структура вирионов - наличие внешней липопротеиновой оболочки, тип симметрии капсида (спиральный, икосаэдрический), структура вирусной РНК (количество нитей, конформация, фрагментированность, полярность). Акцентировано внимание на особенностях репродукции вирусов.

Ключевые слова: вирусы, РНК-геномные, порядки, семейства, подсемейства, роды, виды, типовые, таксономические признаки.

\title{
Taxonomic characteristics of RNA-genomic viruses in vertebrates animals and human
}

\author{
O.S. Kalinina \\ kalininaos@ukr.net \\ Stepan Gzhytskyi National University of Veterinary Medicine and Biotechnologies Lviv,
Pekarska Str., 50, Lviv, 79010, Ukraine
}

\begin{abstract}
The article presents a modern taxonomy and nomenclature of viruses of vertebrates animals and human based on information ICTV release 2016 (ratification 2017). Described the basic criteria for the classification of viruses: characteristics of the viral genome, the mechanism of replication and virions structure. Viruses of vertebrates (1269 species) consist of 5 orders, 38 families, including 12 - DNA-genomic and 26 - RNA-genomic, 12 subfamilies and 233 genera. RNA-genomic viruses of vertebrates (679 species) classified of 4 orders, 26 families, 6 subfamilies and 119 genera. The order Mononegavirales has united family Paramyxoviridae, Pneumoviridae, Rhabdoviridae, Filoviridae, Bornaviridae, Nyamiviridae and Sunviridae, order Nidovirales - family Coronaviridae and Arteriviridae, order Bunyavirales - family Hantaviridae, Nairoviridae, Peribunyaviridae and Phenuiviridae, order Picornavirales - family Picornaviridae. Family Rhabdoviridae, Nodaviridae, Peribunyaviridae, Phenuiviridae, Reoviridae and Birnaviridae, except viruses of vertebrates, contain viruses of insects, and family Rhabdoviridae, Phenuiviridae and Reoviridae - viruses of plants. There is a one of «floating» genus Deltavirus, which is not included of families. The family Reoviridae includes the Eriocheir sinensis reovirus, and the family Birnaviridae - Tellina virus. Described the taxa of viruses: family, subfamily, genera, species. Named typical species genera of viruses. Characterized the basic taxonomic features of RNA-genomic vertebrates viruses of animals and human: the shape, size and structure of virions - the presence of outer membrane lipoprotein, capsid symmetry type (spiral, icosahedral), the structure of the viral RNA (the number of threads, conformation, fragmentation, polarity). The attention to virus reproduction features. Replication of most RNA-genomic viruses occurs in cells of the cytoplasm, except for the representatives of the families Bornaviridae, Nyamiviridae, Orthomyxoviridae, Retroviridae and «floating» genus Deltavirus, which are replicated in the nucleus. Output of the progeny virions in simply organized viruses is due to cell destruction, and in most of the complexly organized viruses - plasma membrane buds, as well as through the membranes of the Golgi complex or the endoplasmic net in combination with exocytosis (Peribunyaviridae, Hantaviridae, Nairoviridae, Phenuiviridae, Flaviviridae, Coronaviridae, Arteriviridae).
\end{abstract}

Key words: viruses, RNA-genomic, orders, family, subfamily, genera, species, type, taxonomic features.

\section{Вступ}

Сучасна класифікація вірусів грунтується на їхніх фундаментальних властивостях, 3 яких провідними $є$ ознаки, що характеризують вірусний геном, механізм реплікації та структуру віріонів (Maclachlan and Dubovi, 2016; Virus Taxonomy, 2016). Віруси хребетних тварин і людини (1269 видів) входять у 5 порядків, 38 родин, 3 яких 12 - ДНК-геномні та 26 - РНКгеномні, 12 підродин і 233 роди. РНК-геномні віруси хребетних (679 видів) класифіковано в 4 порядки, 26 родин, 6 підродин і 119 родів. Порядок Mononegavirales об'єднує родини Paramyxoviridae, Pneumoviridae, Rhabdoviridae, Filoviridae, Bornaviridae, Nyamiviridae i Sunviridae, порядок Nidovirales - родини Coronaviridae та Arteriviridae, порядок Bunyavirales - родини Hantaviridae, Nairoviridae, Peribunyaviridae і Phenuiviridae, порядок Picornavirales - родину Picornaviridae. Родини Rhabdoviridae, Peribunyaviridae, Phenuiviridae, Nodaviridae, Reoviridae і Birnaviridae, крім вірусів хребетних, містять віруси комах, а родини Rhabdoviridae, Phenuiviridae і Reoviridae - віруси рослин. До родини Reoviridae входить реовірус китайських мохнаторуких крабів, а до родини Birnaviridae - вірус морських двостулкових молюсків.
Є один «плавучий» рід Deltavirus, який не належить до родин (Virus Taxonomy, 2016).

Таксономічну характеристику родин РНКгеномних вірусів хребетних тварин і людини подано згідно з інформацією Міжнародного комітету з таксономії вірусів (МКТВ) випуску 2016 р. (ратифікація 2017 p.) (Virus Taxonomy, 2016).

Родина Paramyxoviridae (параміксовіруси) 7 родів, 49 видів.

1. Рід Aquaparamyxovirus (1 вид): аквапараміксовірус лососів*. 2. Рід Avulavirus (13 видів): авулавіруси птахів $1^{*}, 2,3,4,5,6,7,8,9,10,11,12,13$. 3. Рід Ferlavirus (1 вид): ферлавірус рептилій*. 4. Рід Henipavirus (5 видів): хеніпавіруси Хендра*, Ніпах, Кедр, Моджіанг, ганських кажанів. 5. Рід Morbillivirus (7 видів): морбіллівіруси кору*, чуми великої рогатої худоби, дрібних жуйних, собак, тюленів, котів, китоподібних.6. Рід Respirovirus (5 видів): респіровіруси мишей*, людини 1,3 , великої рогатої худоби 3 , свиней 1. 7. Рід Rubulavirus (17 видів): рубулавіруси епідемічного паротиту*, людини 2, 4, ссавців 5, мавп, свиней, Мапуера, Созуга, Ачимота 1, 2, епідемічного паротиту кажанів, Мененгле, Тевіот, Тіоман, Тухоко $1,2,3$.

*Типовий вид. 
Родина Pneumoviridae (пневмовіруси) - 2 роди, 5 видів.

1. Рід Metapneumovirus (2 види): метапневмовіруси птахів*, людини. 2. Рід Orthopneumovirus (3 види): ортопневмовіруси людини*, великої рогатої худоби, мишей.

Родина Rhabdoviridae (рабдовіруси) - 10 родів, 76 видів.

1. Рід Ephemerovirus (8 видів): ефемеровіруси гарячки великої рогатої худоби*, річки Аделаїде, Берріма, Кімберлі, Кулпінья, Котонкан, Ободгіанг. Ята. 2. Рід Ledantevirus (14 видів): ледантевіруси Ле Дантек*, Барур, Фікіріні, Фукуока, Нішимура, каньйону Керн, Кураліба, Коленте, Кумасі, кажанів гори Елгон, Нкольбіссон, Ойта, Ухань, Йонгджія. 3. Рід Lissavirus (14 видів): ліссавіруси сказу*, європейських кажанів 1, 2, австралійських кажанів, кажанів Бокело, кажанів Лагос, кажанів Шимоні, західно-кавказьких кажанів, Ікома, Дувенхаге, Іркут, Мокола, Худжанд, Араван. 4. Рід Novirhabdovirus (4 види): новірабдовіруси лососевих*, риб, хіраме, змієголовів. 5. Рід Perhabdovirus (3 види): перабдовіруси окунів*, морських форелей, вугрів. 6. Рід Sprivivirus (2 види): спрівівіруси коропів*, мальків щук. 7. Рід Sripuvirus (5 видів): сріпувіруси Ньяха*, Алмпівар, Чако, Сена Мадурейра, Сріпур. 8. Рід Tibrovirus (6 видів): тібровіруси Тіброгарган*, Нижнього Конго, прибережних рівнин, Екпома 1, Екпома 2, прісноводних притоків. 9. Рід Tupavirus (3 види): тупавіруси Дарем*, Клемет, тупай. 10. Рід Vesiculovirus (16 видів): везикуловіруси Індіана*, Алагоас, Кокал, Нью-Джерсі, американських кажанів, Караяс, Чандіпура, Ісфаган, Юрона, джерела Мальпіс, Мараба, Морретон, Перінет, Пірі, Південь Богдановац, Раді.

Некласифікований вірус (1 вид): вірус Мусса.

Родина Filoviridae (філовіруси) - 3 роди, 7 видів.

1. Рід Cuevavirus (1 вид ): куевавірус Лловіу*. 2. Рід Ebolavirus (5 видів): еболавіруси Заїр*, Судан, Рестон, Бундібуджио, Тай Ліс. 3. Рід Marburgvirus (1 вид): марбургвірус Марбург*.

Родина Bornaviridae (борнавіруси) - 1 рід, 8 видів.

Рід Bornavirus (8 видів): борнавіруси ссавців 1*, 2, горобцеподібних 1,2 , папугоподібних 1,2 , водоплавних птахів 1, аспідових 1.

Родина Nyamiviridae (ньямівіруси) - 1 рід, 3 види.

Рід Nyavirus (3 види): ньявіруси Ньяманіні*, Мідвей, Сьєрра-Невада.

Родина Sunviridae (сунвіруси) - 1 рід, 1 вид.

Рід Sunshinevirus (1 вид): сунчіневірус рептилій $1 *$.

Родина Orthomyxoviridae (ортоміксовіруси) 7 родів, 9 видів.

1. Рід Influenzavirus А (1 вид): вірус грипу $\mathrm{A}^{*}$. 2. Рід Influenzavirus В (1 вид): вірус грипу В*. 3. Рід Influenzavirus C (1 вид): вірус грипу $\mathrm{C}^{*}$. 4. Рід Influenzavirus D (1 вид): вірус грипу D*. 5. Рід Isavirus (1 вид): вірус інфекційної анемії лососів*. 6. Рід Quaranjavirus (2 види): вірус Кваранфіл*, атола Джонстон. 7. Рід Thogotovirus (2 види): вірус Тогото*.

Родина Arenaviridae (аренавіруси) - 2 роди, 36 видів.
1. Рід Mammarenavirus (33 види): маммаренавіруси лімфоцитарного хоріоменінгіту*, Альпагуайо, Амапаpi, Каньйону Ведмедя, Чапаре, Капіксі, Флексал, Гайро, Гуанаріто, Іппі, Хунін, Ласса, Латіно, річки Лоей, Лухо, Луна, Ланк, Мачупо, Маріентал, Меріне Волк, Мобала, Мопейа, Окаханджа, Оліверос, Парана, Пічінде, Пірітал, Сабіа, Солвезі, Такарібе, Таміамі, Вайтватер Арройо, Веньчжоу. 2. Рід Reptarenavirus (3 види): рептаренавіруси плазунів $1 *, 2,3$.

Родина Peribunyaviridae (перібуньявіруси) 1 рід, 48 видів.

Рід Orthobunyavirus (48 видів): ортобуньявіруси Буньямвера*, Акара, Акабане, Аладжела, Анофелес А, В, Бакеу, Батама, Беневідес, Бертіога, Біміті, Ботамбі, Бушбуш, Бвамба, каліфорнійського енцефаліту, Кепім, Карапару, Кату, Естеро Ріл, Гамбоа, Гуаяра, Гуама, Гуаро, Кенг Кой, Кайрі, Кунгол, М'Поко, Мадрид, Мейн Дрейн, Манзанілла, Марітуба, Мінатітлан, Ньяндо, Оліфантсвлей, Орібока, Оропауч, Патуа, Сатупері, Сімбу, Шамонда, Шуні, Такаюма, Тете, Тімірі, Тімботеу, Тарлок, Вьєомія, Зегла.

Родина Hantaviridae (хантавіруси) - 1 рід, 41 вид.

Рід Orthohantavirus (41 вид): ортохантавіруси Хантаан*, Амга, Андес, Асама, Асіккала, Баю, каналу Блек Крік, Боу, Брюгге, Кано Дельгадіто, Као Банг, Чокльо, Дабішен, Добрава - Бєлград, каньйону Ель Моро, Фігонг, Фусун, Імджин, Чеджу, Кенкеме, Хабаровськ, Чорної Лагуни, Лайбінь, Лунцюань, Лаксі, Мапорол, Монтано, Некоклі, Нова, Оксбоу, Проспект Хілл, Пуумала, Кесон, Рокпорт, Сангассу, Сеул, Сін Нобре, Таїланд, Тоттапалаям, Тула, Якеші.

Родина Nairoviridae (найровіруси) - 1 рід, 12 видів.

Рід Orthonairovirus (12 видів): ортонайровіруси Дагбі*, Бурана, геморагічної гарячки Крим - Конго, Дера-Газі-Хан, Хазара, Хьюз, Касокеро, Кетера, хвороби овець Найробі, Кальюб, Сахалін, Тіафора.

Родина Phenuiviridae (фенуівіруси) - 1 рід, 10 видів.

Рід Phlebovirus (10 видів): флебовіруси гарячки долини Ріфт*, москітної гарячки Неаполя, Буяру, Кандіру, Чілібре, Фріджолс, Пунта Торо, Сейлхабед, Уукуніемі, SFTS.

Родина Coronaviridae (коронавіруси) 2 підродини, 6 родів, 39 видів.

I. Підродина Coronavirinae (4 роди) 1. Рід Alphacoronavirus (11 видів): альфакоронавірус 1*, коронавіруси людини 229E, NL63, норок 1, кажанів HKU10, CDPHE15, довгокрилих кажанів 1, HKU8, підковоносів HKU2, жовтих кажанів 512, вірус епізоотичної діареї свиней. 2. Рід Betacoronavirus (9 видів): коронавіруси мишей*, людини HKU1, важкого гострого респіраторного синдрому, респіраторного синдрому Близького Сходу, їжаків 1, нетопирів HKU5, криланів HKU9, бамбукових кажанів HKU4, бетакоронавірус 1. 3. Рід Deltacoronavirus (8 видів): коронавіруси солов'їв HKU11*, молочниць HKU12, муній HKU13, HKU15, очеретянок HKU21, нічних чапель HKU19, білоочкових HKU16, свищів HKU20. 4. Рід Gammacoronavirus (2 види): коронавіруси птахів*, білуг SW1. 
II. Підродина Torovirinae (2 роди) 1. Рід Bafinivirus (2 види): вірус білих лящів*, нідовірус гольянів 1. 2. Рід Torovirus (4 види): торовіруси коней*, людини, великої рогатої худоби, свиней.

Некласифіковані віруси (3 види): нідовіруси великої рогатої худоби 1 , чавич 1 , королівських пітонів 1.

Родина Arteriviridae (артерівіруси) - 5 родів, 17 видів.

1. Рід Dipartevirus (1 вид): вірус хиткої хвороби опосумів*. 2. Рід Equartevirus (1 вид): вірус артеріїту коней*. 3. Рід Nesartevirus (1 вид): артерівірус африканських сумчастих пацюків*. 4. Рід Porartevirus (4 види): віруси підвищення рівня лактатдегідрогенази*, репродуктивно-респіраторного синдрому свиней 1, 2, артерівірус пацюків 1. 5. Рід Simartevirus (10 видів): вірус геморагічної гарячки мавп*, артерівірус мавп Де Бразза, віруси верветок вільного штату, ведмежих павіанів кінда Кафуе, червоних колобусів Кібале 1, 2, червонохвостих мавп Кібале 1, жовтих павіанів Мікумі 1, Пебья, геморагічного енцефаліту мавп.

Родина Togaviridae (тогавіруси) - 2 роди, 32 види.

1. Рід Alphavirus (31 вид): віруси Сіндбіс*, Аура, лісу Барма, Бебару, Кабассу, Чікункунья, східного енцефаломієліту коней, західного енцефаломієліту коней, венесуельського енцефаломієліту коней, Ейлат, Еверглейдс, Форт Морган, Гета, надгір'я Джей, Мадаріага, Майяро, Міддельбург, Моссо дас Педрас, Мукамбо, Ндуму, О’ньонг-ньонг, Піксуна, Ріо Негро, річки Росс, лісу Семліки, Тонате, Трокара, Уна, Ватароа, південних морських слонів, хвороби підшлункової залози лососів. 2. Рід Rubivirus (1 вид): вірус краснухи*.

Родина Flaviviridae (флавівіруси) - 4 роди, 82 види.

1. Рід Flavivirus (53 види): віруси жовтої гарячки*, Апої, Ароа, Багаза, Бензі, Боубоуі, кажанів Букаласа, Каціпакор, Острова Кері, Каубоун Рідж, кажанів Дакар, Денге, Едж Хілл, кажана Ентеббе, Гаджец Галлі, Ільєус, менінгоенцефаліту індиків Ізраїля, японського енцефаліту, Югра, Ютіапа, Кадам, Кедоугоу, Кокобера, Кутанго, хвороби лісу Кьясанур, Лангат, хвороби Люпінга, Меабан, Модок, лейкоенцефалопатії коротковухих кажанів Монтана, енцефаліту долини Муррей, Нтайя, омської геморагічної гарячки, кажанів Пномпень, Повассан, Ріо Браво, Ройял Фарм, Сабоя, Сал Віея, Сан Перліта, рифу Саумарез, Сепік, енцефаліту Сент Луїс, Тембусу, кліщового енцефаліту, Тюленячий, Уганда S, Усуту, Вессельсброн, Західного Нілу, Яунде, Йокосе, Зіка. 2. Рід Hepacivirus (14 видів): гепацівіруси C*, A, B, D, E, F, G, H, I, J, K, L, M, N. 3. Рід Pegivirus (11 видів): пегівіруси А*, B, C, D, E, F, G, H, I, J, К. 4. Рід Pestivirus (4 види): віруси діареї великої рогатої худоби $1 *, 2$, класичної чуми свиней, прикордонної хвороби.

Родина Picornaviridae (пікорнавіруси) - 35 родів, 57 видів.

1. Pid Ampivirus (1 вид): ампівірус А. 2. Рід Aphthovirus (4 види): віруси ящуру*, риніту великої рогатої худоби А, В, риніту коней А. 3. Рід Aquamavirus (1 вид): аквамавірус А*. 4. Рід
Avihepatovirus (1 вид): авігепатовірус $\mathrm{A}^{*}$. 5. Рід Avisivirus (1 вид): авісівірус А*. 6. Рід Cardiovirus (3 види): кардіовіруси А*, В, С. 7. Рід Cosavirus (1 вид): косавірус А*. 8. Рід Dicipivirus (1 вид): кадіцівірус А*. 9. Рід Enterovirus (12 видів): ентеровіруси С*, А, В, D, E, F, G, Н, J, риновіруси А, В, С. 10. Рід Erbovirus (1 вид): вірус риніту коней $\mathrm{B}^{*}$. 11. Рід Gallivirus (1 вид): галлівірус A*. 12. Pid Harkavirus (1 вид): харкавірус А. 13. Рід Hepatovirus (1 вид): гепатовірус А*. 14. Рід Hunnivirus (1 вид): хуннівірус А. 15. Рід Kobuvirus (3 види): айчівіруси А*, В, С. 16. Рід Kunsagivirus (1 вид): кунсагівірус $\mathrm{A}^{*}$. 17. Рід Limnipivirus (3 види): лімніпівіруси А*, В, С. 18. Рід Megrivirus (1 вид): мелегрівірус А*. 19. Рід Mischivirus (1 вид): мішівірус А*. 20. Рід Mosavirus (1 вид): мосавірус А*. 21. Рід Oscivirus (1 вид): осцівірус $A^{*}$. 22. Рід Parechovirus (2 види): пареховіруси А*, В. 23. Рід Pasivirus (1 вид): пасівірус А*. 24. Рід Passerivirus (1 вид): пассерівірус А*. 25. Рід Potamipivirus (1 вид): потаміпівірус А*. 26. Рід Rosavirus (1 вид): росавірус A*. 27. Рід Rabovirus (1 вид): рабовірус А. 28. Рід Sakobuvirus (1 вид): сакобувірус А*. 29. Рід Salivirus (1 вид): салівірус А*. 30. Рід Sapelovirus (3 види): сапеловіруси А*, В, птахів. 31. Рід Senecavirus (1 вид): сенекавірус А*. 32. Рід Sicinivirus (1 вид): сіцінівірус А. 33. Рід Teschovirus (1 вид): тешовірус А*. 34. Рід Torchivirus (1 вид): торчівірус А. 35. Рід Tremovirus (1 вид): тремовірус A*.

Родина Caliciviridae (каліцівіруси) - 5 родів, 7 видів.

1. Рід Lagovirus (2 види): віруси геморагічної хвороби кролів*, синдрому європейських зайців-русаків. 2. Рід Nebovirus (1 вид): вірус Ньюбері-1*. 3. Рід Norovirus (1 вид): вірус Норволк*. 4. Рід Sapovirus (1 вид): вірус Саппоро*. 5. Рід Vesivirus (2 види): вірус везикулярної екзантеми свиней*, каліцівірус котів.

Родина Astroviridae (астровіруси) - 2 роди, 22 види.

1. Рід Avastrovirus 1 (3 види): авастровіруси $1 *, 2$, 3. 2. Рід Mamastrovirus (19 видів): мамастровіруси $1 *$, 2, 3, 4, 5, 6, 7, 8, 9, 10, 11, 12, 13, 14, 15, 16, 17, 18, 19.

Родина Нереviridae (гепевіруси) - 2 роди, 5 видів.

1. Рід Orthohepevirus (4 види): ортогепевіруси А*, B, C, D. 2. Рід Piscihepevirus (1 вид): пісцігепевірус $\mathrm{A}^{*}$.

Родина Nodaviridae (нодавіруси) - 2 роди, 5 видів.

1. Рід Alphanodavirus (1 вид): вірус Нодамура. 2. Рід Betanodavirus (4 види): віруси некрозу нервової тканини смугастих джеків*, балфінських камбал, червоних плямистих груперів, тигрових фугу.

Родина Retroviridae (ретровіруси) - 2 підродини, 7 родів, 55 видів.

I. Підродина Orthoretrovirinae (6 родів) 1. Рід Alpharetrovirus (9 видів): віруси лейкозу птахів*, мієлобластозу птахів, мієлоцитоматозу птахів, саркоми Payca, карциноми птахів Mill Hill 2, саркоми птахів CT10, саркоми птахів Фуджінамі, саркоми птахів UR2, саркоми птахів Y73. 2. Рід Betaretrovirus (5 видів): віруси пухлини молочних залоз мишей*, лангурів, мавп Мейсон - Пфайзера, ретровіруси овець Джаагсіекте, саймірі. 3. Рід Deltaretrovirus (4 види): вірус 
лейкозу великої рогатої худоби*, Т-лімфотропні віруси приматів 1, 2, 3. 4. Рід Epsilonretrovirus (3 види): віруси шкірної саркоми судаків*, епідермальної гіперплазії судаків 1, 2. 5. Рід Gammaretrovirus (18 видів): віруси лейкозу мишей*, лейкемії котів, лейкемії мавп гібонів, саркоми шерстистих мавп, саркоми котів Гарднер - Арнштайн, Харді - Цукерман, Снайдер Тейлен, саркоми мишей Харві, Фінкель - Біскіс Джанкінс, Кірстен, Молоні, ретикулоендотеліозу, некрозу селезінки качок, онковіруси типу-С свиней, мурчаків, синцитіальний вірус курчат, ретровіруси коал, гадюк. 6. Рід Lentivirus (10 видів): віруси імунодефіциту людини $1 *, 2$, мавп, великої рогатої худоби, котів, інфекційної анемії коней, вісни/меді, артритуенцефаліту кіз, хвороби Джембрана, лентівірус пум.

II. Підродина Spumaretrovirinae (1 рід) Рід Spumavirus (6 видів): пінисті віруси мавп*, великої рогатої худоби, коней, котів, мавпячі пінисті віруси макак, африканських зелених мавп.

Родина Reoviridae (реовіруси) - 2 підродини, 6 родів, 46 видів.

I. Підродина Sedoreovirinae (3 роди) 1. Рід Orbivirus (22 види): віруси блутанга*, африканської чуми коней, перуанської чуми коней, енцефалозу коней, епізоотичної геморагічної хвороби, Чангвінола, Ченуда, ущелини Чобар, Корріпарта, Евбенандже, Великого Острова, Ієрі, Лебомбо, Орунго, Пальям, річки Санкт Круа, Уматілла, Вад Медані, Валлал, Варрего, Вонгорр, орбівірус Юньнань. 2. Рід Rotavirus (9 видів): ротавіруси А*, B, C, D, E, F, G, H, I. 3. Рід Seadornavirus (3 види): віруси Банна, Кадіпіро, Ляонін.

II. Підродина Spinareovirinae (3 роди) 1. Рід Aquareovirus (7 видів): аквареовіруси А* , В, C, D, Е, F, G. 2. Рід Coltivirus (2 види): віруси колорадської кліщової гарячки*, Еяч. 3. Рід Orthoreovirus (6 видів): ортореовіруси ссавців*, птахів, бабуїнів, Бухти Нельсона, рептилій, риб. 4 види.

Родина Birnaviridae (бірнавіруси) - 3 роди,

1. Рід Aquabirnavirus (2 види): віруси інфекційного некрозу підшлункової залози*, асциту жовтохвостів. 2. Рід Avibirnavirus (1 вид): вірус інфекційної бурсальної хвороби*. 3. Рід Blosnavirus (1 вид): вірус мармурових змієголовів*.

Родина Picobirnaviridae (пікобірнавіруси) - 1 рід, 2 види.

Рід Picobirnavirus (2 види): пікобірнавіруси людини*, кролів.

«Плавучий» рід Deltavirus (дельтавірус) - 1 вид: вірус гепатиту дельта*.

Основні таксономічні ознаки родин РНК-геномних вірусів хребетних тварин і людини подано в таблиці 1 (Maclachlan and Dubovi, 2016; Virus Taxonomy, 2016).

Таблиия 1

\section{Основні таксономічні ознаки РНК-геномних вірусів хребетних тварин і людини}

\begin{tabular}{|c|c|c|c|c|c|}
\hline Родина & РНК & Форма віріона & Розміривіріона (нм) & $\begin{array}{l}\text { Супер- } \\
\text { капсид }\end{array}$ & $\begin{array}{c}\text { Тип симетрії } \\
\text { капсиду }\end{array}$ \\
\hline 1 & 2 & 3 & 4 & 5 & 6 \\
\hline $\begin{array}{l}\text { Paramyxoviridae } \\
\text { (параміксовіруси) }\end{array}$ & $\begin{array}{c}\text { 1л (л) } \\
-\mathrm{H}\end{array}$ & $\begin{array}{l}\text { Плеоморфна, } \\
\text { сферична }\end{array}$ & $150-350$ & $\epsilon$ & Спіральний \\
\hline $\begin{array}{l}\text { Pneumoviridae } \\
\text { (пневмовіруси) }\end{array}$ & $\begin{array}{c}\text { 1л (л) } \\
-\mathrm{H}\end{array}$ & $\begin{array}{l}\text { Сферична, } \\
\text { ниткоподібна }\end{array}$ & $\begin{array}{c}80-140 \\
250-600 \\
2000 \times 70-190\end{array}$ & $\epsilon$ & Спіральний \\
\hline $\begin{array}{l}\text { Rhabdoviridae } \\
\text { (рабдовіруси) }\end{array}$ & $\begin{array}{c}\text { 1л (л) } \\
-\mathrm{H}\end{array}$ & Кулеподібна & $130-380 \times 60-80$ & $\epsilon$ & Спіральний \\
\hline $\begin{array}{l}\text { Filoviridae } \\
\text { (філовіруси) }\end{array}$ & $\begin{array}{c}\text { 1л (л) } \\
-\mathrm{H}\end{array}$ & $\begin{array}{l}\text { Плеоморфна, } \\
\text { ниткоподібна }\end{array}$ & 790,970 або $1400 \times 80$ & $\epsilon$ & Спіральний \\
\hline $\begin{array}{l}\text { Bornaviridae } \\
\text { (борнавіруси) }\end{array}$ & $\begin{array}{c}\text { 1л (л) } \\
-\mathrm{H}\end{array}$ & Сферична & $70-130$ & $\epsilon$ & Спіральний \\
\hline $\begin{array}{l}\text { Nyamiviridae } \\
\text { (ньямівіруси) }\end{array}$ & $\begin{array}{c}\text { 1л (л) } \\
-\mathrm{H}\end{array}$ & Сферична & $100-130$ & $\epsilon$ & Спіральний \\
\hline $\begin{array}{l}\text { Sunviridae } \\
\text { (сунвіруси) }\end{array}$ & $\begin{array}{c}\text { 1л (л) } \\
-\mathrm{H}\end{array}$ & Сферична & & $\epsilon$ & Спіральний \\
\hline $\begin{array}{l}\text { Orthomyxoviridae } \\
\text { (ортоміксовіруси) }\end{array}$ & $\begin{array}{c}\text { 1л (ф) } \\
-\mathrm{H}\end{array}$ & $\begin{array}{l}\text { Плеоморфна, } \\
\text { сферична }\end{array}$ & $80-120$ & $\epsilon$ & Спіральний \\
\hline $\begin{array}{l}\text { Arenaviridae } \\
\text { (аренавіруси) }\end{array}$ & $\begin{array}{c}\text { 1л (фк) } \\
-{ }_{-H}\end{array}$ & $\begin{array}{l}\text { Плеоморфна, } \\
\text { сферична }\end{array}$ & $50-300$ & $\epsilon$ & Спіральний \\
\hline $\begin{array}{l}\text { Peribunyaviridae } \\
\text { (перібуньявіруси) }\end{array}$ & $\begin{array}{c}\text { 1л (фк) } \\
-\mathrm{H} \\
\end{array}$ & Сферична & $80-120$ & $\epsilon$ & Спіральний \\
\hline $\begin{array}{l}\text { Hantaviridae } \\
\text { (хантавіруси) }\end{array}$ & $\begin{array}{c}\text { 1л (фк) } \\
-\mathrm{H}\end{array}$ & Сферична & $80-120$ & $\epsilon$ & Спіральний \\
\hline $\begin{array}{l}\text { Nairoviridae } \\
\text { (найровіруси) }\end{array}$ & $\begin{array}{c}1 \text { 1л (фк) } \\
-\mathrm{H} \\
\end{array}$ & Сферична & $80-120$ & $\epsilon$ & Спіральний \\
\hline $\begin{array}{l}\text { Phenuiviridae } \\
\text { (фенуівіруси) }\end{array}$ & $\begin{array}{c}\text { 1л (фк) } \\
-\mathrm{H}\end{array}$ & Сферична & $80-120$ & $\epsilon$ & Спіральний \\
\hline $\begin{array}{l}\text { Coronaviridae } \\
\text { (коронавіруси) }\end{array}$ & $\begin{array}{c}1 \text { л (л) } \\
+ \text { +н } \\
\end{array}$ & $\begin{array}{l}\text { Плеоморфна, } \\
\text { сферична }\end{array}$ & $80-220$ & $\epsilon$ & Спіральний \\
\hline $\begin{array}{l}\text { Arteriviridae } \\
\text { (артерівіруси) }\end{array}$ & $\begin{array}{c}\text { 1л (л) } \\
+\mathrm{H}\end{array}$ & Сферична & $45-60$ & $\epsilon$ & $\begin{array}{l}\text { Ікосаедраль- } \\
\text { ний }\end{array}$ \\
\hline
\end{tabular}


Продовження табл. 1

\begin{tabular}{|c|c|c|c|c|c|}
\hline 1 & 2 & 3 & 4 & 5 & 6 \\
\hline $\begin{array}{l}\text { Togaviridae } \\
\text { (тогавіруси) }\end{array}$ & $\begin{array}{c}\text { 1л (л) } \\
+\mathrm{H}\end{array}$ & Сферична & $65-70$ & $\epsilon$ & Ікосаедральний \\
\hline $\begin{array}{l}\text { Flaviviridae } \\
\text { (флавівіруси) }\end{array}$ & $\begin{array}{c}\text { 1л (л) } \\
+\mathrm{H}\end{array}$ & Сферична & $40-60$ & $\epsilon$ & Ікосаедральний \\
\hline $\begin{array}{l}\text { Picornaviridae } \\
\text { (пікорнавіруси) }\end{array}$ & $\begin{array}{c}\text { 1л (л) } \\
+\mathrm{H}\end{array}$ & Сферична & $20-32$ & Немає & Ікосаедральний \\
\hline $\begin{array}{l}\begin{array}{l}\text { Caliciviridae } \\
\text { (каліцівіруси) }\end{array} \\
\end{array}$ & $\begin{array}{c}1 л \text { (л) } \\
+\mathrm{H}\end{array}$ & $\begin{array}{l}\text { Сферична, } \\
\text { ікосаедральна }\end{array}$ & $27-40$ & Немає & Ікосаедральний \\
\hline $\begin{array}{l}\text { Astroviridae } \\
\text { (астровіруси) }\end{array}$ & $\begin{array}{c}\text { 1л (л) } \\
+{ }_{H}\end{array}$ & Сферична & $28-30$ & Немає & Ікосаедральний \\
\hline $\begin{array}{l}\text { Hepeviridae } \\
\text { (гепевіруси) }\end{array}$ & $\begin{array}{c}\text { 1л (л) } \\
+ \text { +н }\end{array}$ & Сферична & $27-34$ & Немає & Ікосаедральний \\
\hline $\begin{array}{l}\text { Nodaviridae } \\
\text { (нодавіруси) }\end{array}$ & $\begin{array}{c}\text { 1л }(\phi) \\
+_{H}\end{array}$ & Сферична & $25-35$ & Немає & Ікосаедральний \\
\hline $\begin{array}{l}\text { Retroviridae } \\
\text { (ретровіруси) }\end{array}$ & $\begin{array}{c}1 л \text { (л) } \\
+ \text { +H }\end{array}$ & Сферична & $80-100$ & $\epsilon$ & Ікосаедральний \\
\hline $\begin{array}{l}\text { Reoviridae } \\
\text { (реовіруси) }\end{array}$ & 2л (ф) & Сферична & $60-80$ & Немає & Ікосаедральний \\
\hline $\begin{array}{l}\text { Birnaviridae } \\
\text { (бірнавіруси) }\end{array}$ & 2л (ф) & Ікосаедральна & $60-70$ & Немає & Ікосаедральний \\
\hline $\begin{array}{l}\text { Picobirnaviridae } \\
\text { (пікобірнавіруси) }\end{array}$ & 2л (ф) & Сферична & $33-37$ & Немає & Ікосаедральний \\
\hline $\begin{array}{l}\text { Deltavirus } \\
\text { (дельтавірус) }\end{array}$ & $\begin{array}{c}\text { 1л (к) } \\
-\mathrm{H}\end{array}$ & Сферична & $36-43$ & $\epsilon$ & \\
\hline
\end{tabular}

Примітка: 1л - одноланцюгова; 2л - дволанцюгова; л - лінійна; к - кільцева; ф - фрагментована; +н - плюс-нитка; -н мінус-нитка.

Реплікація більшості РНК-геномних вірусів відбувається в цитоплазмі клітин, за винятком представників родин Bornaviridae, Nyamiviridae, Orthomyxoviridae, Retroviridae i «плавучого» роду Deltavirus, які реплікуються в ядрі. Вихід віріонів потомства у просто організованих вірусів здійснюється внаслідок деструкції клітин, а у більшості складно організованих вірусів - брунькуванням через плазмолему, а також через мембрани комплексу Гольджі або ендоплазматичної сітки в поєднанні 3 екзоцитозом (Peribunyaviridae, Hantaviridae, Nairoviridae, Phenuiviridae, Flaviviridae, Coronaviridae, Arteriviridae) (Maclachlan and Dubovi, 2016; Virus Taxonomy, 2016).

\section{Висновки}

Віруси хребетних тварин і людини (1269 видів) входять у 5 порядків, 38 родин, 3 яких 12 - ДНКгеномні та 26 - РНК-геномні, 12 підродин і 233 роди.
РНК-геномні віруси хребетних (679 видів) класифіковано в 4 порядки, 26 родин, 6 підродин і 119 родів.

\section{Бібліографічні посилання}

Maclachlan, N., Dubovi, E.J. (2016). Fenner's Veterinary Virology. 5th Edition. Virology Laboratory, Animal Health Diagnostic Center, College of Veterinary Medicine, Cornell University, Ithaca, NY, USA. Academic Press. 16th November 2016, 602.

Virus Taxonomy (2016). Release International Committee on Taxonomy of Viruses [Electronic resourse]. Mode of acces: http://www.ictvonline.org/ virustaxonomy.asp. - Title from the screen.

Received 11.09.2017 Received in revised form 29.09.2017 Accepted 2.10.2017 